Research Paper

\title{
Swainsonine Activates Mitochondria-mediated Apoptotic Pathway in Hu- man Lung Cancer A549 Cells and Retards the Growth of Lung Cancer Xen- ografts
}

\author{
Zhaocai Li\#, Xingang Xu\#, Yong Huang, Li Ding, Zhisheng Wang, Gaoshui Yu, Dan Xu, Wei Li, Dewen \\ Tong ${ }^{凶}$
}

College of Veterinary Medicine, Northwest A\&F University, Yangling, Shaanxi 712100, P.R. China

\# These authors contributed equally to this work.

$\triangle$ Corresponding author: Tel: 0086-29-8709-1622. Fax: 0086-29-8709-1032. E-mail: dwtong@nwsuaf.edu.cn.

(c) Ivyspring International Publisher. This is an open-access article distributed under the terms of the Creative Commons License (http://creativecommons.org/ licenses/by-nc-nd/3.0/). Reproduction is permitted for personal, noncommercial use, provided that the article is in whole, unmodified, and properly cited.

Received: 2011.11.29; Accepted: 2012.02.19; Published: 2012.02.24

\begin{abstract}
Swainsonine (I, 2, 8-trihyroxyindolizidine, SW), a natural alkaloid, has been reported to exhibit anti-cancer activity on several mouse models of human cancer and human cancers in vivo. However, the mechanisms of SW-mediated tumor regression are not clear. In this study, we investigated the effects of SW on several human lung cancer cell lines in vitro. The results showed that SW significantly inhibited these cells growth through induction of apoptosis in different extent in vitro. Further studies showed that SW treatment up-regulated Bax, down-regulated $\mathrm{Bcl}-2$ expression, promoted $\mathrm{Bax}$ translocation to mitochondria, activated mitochondria-mediated apoptotic pathway, which in turn caused the release of cytochrome c, the activation of caspase- 9 and caspase-3, and the cleavage of poly (ADP-ribose) polymerase (PARP), resulting in A549 cell apoptosis. However, the expression of Fas, Fas ligand (FasL) or caspase-8 activity did not appear significant changes in the process of SW-induced apoptosis. Moreover, SW treatment inhibited Bcl-2 expression, promoted Bax translocation, cytochrome c release and caspase- 3 activity in xenograft tumor cells, resulting in a significant decrease of tumor volume and tumor weight in the SW-treated xenograft mice groups in comparison to the control group. Taken together, this study demonstrated for the first time that SW inhibited A549 cancer cells growth through a mitochondria-mediated, caspase-dependent apoptotic pathway in vitro and in vivo.
\end{abstract}

Key words: swainsonine, apoptosis, caspase, mitochondrial pathway, A549 cells

\section{Introduction}

Swainsonine (1, 2, 8-trihyroxyindolizidine, SW), a natural plant alkaloid, was first isolated from the Australian legume Swainsona canescens and then identified in many Astragalus and Oxytropis species (Leguminosae) [1, 2]. These plants are commonly called locoweeds, found in China, the United States, and some other parts of the world [2,3]. In China, there are at least 10 species of locoweeds widely growing in the western rangelands covering up to 11 million hectares [4, 5], which will provide plentiful resources for SW study and application in different field.

SW has attracted great interest for its anti-tumor property. SW not only suppresses the growth and metastasis of murine B16F10 melanoma and MDAY-D2 lymphoid tumor cells in syngeneic mice, but also reduces the growth rate of human melanoma, colon and gastric carcinoma cells, as well as C6 glioma cells in vitro and in vivo [6-11]. Clinical trials with SW, 
as an anti-tumor drug, have shown obviously curative effects with well tolerance in the patients with advanced malignancies $[12,13]$. SW has also been shown to promote anti-tumor immunomodulatory activities of immune system and protect both murine and human bone marrow against the toxicity of chemotherapeutic drugs [14-16]. Additionally, the enhancement effects of SW for the performance of anti-tumor agents such as 5-Fu and cisplatin have also reported $[17,18]$. All of these studies provide rational for exploring SW as an anti-tumor agent.

Apoptosis is a tightly controlled physiological process that plays a critical role in developmental modeling, homeostasis maintenance, immune repertoires, and clearance of infected or transformed cells [19]. Apoptosis can be triggered by various extracellular and intracellular stimuli via either an extrinsic or intrinsic pathway in different cells [20]. The extrinsic pathway is initiated by cell surface receptors, while the intrinsic pathway is initiated by a mitochondria mediated death signaling cascade [20]. Compared with nontransformed cells, tumor cells are insensitive to some physiological stimuli that trigger physiological cell death. For most of chemotherapy drugs, activation of apoptotic pathways to kill tumor cells is a predominant anti-tumor mechanism. Previous studies showed that SW inhibited the growth of human gastric carcinoma SGC-7901 cells and rat C6 glioma cells via induction of apoptosis $[9,10]$, suggesting that SW might serve as an apoptotic inducer in tumor cells. Up to date, however, the molecular mechanisms have not yet been investigated. Therefore, we conducted this study to examine the effects of SW on human lung cancer A549 cells both in vivo and in vitro, and elucidate the possible mechanism involved in this process.

\section{Materials and methods Reagents}

SW was isolated from Oxytropis kansuensis Bunge (a kind of locoweed widely distributed in the west of China) and identified by interpretation of spectral data (MS, 1H NMR, 13C NMR, 2D NMR) as described previously [5]. Its purity was evaluated to be above $99 \%$. The alkaloid was dissolved in $\mathrm{Ca}^{2+}$ - and $\mathrm{Mg}^{2+}-$ free PBS (0.01 M, pH7.2), at $10 \mathrm{mM}$ as stock solution, sterilized by ultrafiltration, and stored at $-20^{\circ} \mathrm{C}$.

RPMI-1640 medium and newborn bovine serum was obtained from GIBCO BRL (Grand Island, NY, US). 3-(4,5-Dimetylthiazol-2-yl)-2,5-diphenyltetrazolium bromide (MTT), 4',6-diamidino-2-phenylindole (DAPI), acridine orange (AO), ethidium bromide (EB), z-VAD-fmk， z-DEVD-fmk, z-LEHD-fmk and z-IETD-fmk were all purchased from Sigma-Aldrich (St. Louis, MO, US). Mouse monoclonal antibodies against caspase-8, caspase-9, caspase-3, Bcl-2, Bax, Fas, Fas ligand (FasL), cytochrome c, cytochrome c oxidase subunit IV (COX IV), poly (ADP-ribose) polymerase (PARP) and $\beta$-actin were purchased from Santa Cruz Biotechnology, Inc. (Santa Cruz, CA, US). Horseradish peroxidase-conjugated secondary antibody was purchased from Wuhan Boster Bio-Engineering Co., Ltd. (Wuhan, China). All other chemicals and reagents were of the highest quality and obtained from standard commercial sources.

\section{Cells culture and treatment}

Human lung cancer cell lines A549, Calu-3, SPC-A-1 and H1299 were obtained from the Cell Bank of Type Culture Collection of Chinese Academy of Sciences (Shanghai, China) and cultured in RPMI-1640 medium (GIBCO BRL) supplemented with $10 \%$ new born bovine serum (GIBCO BRL), 100 $\mathrm{U} / \mathrm{ml}$ penicillin and $100 \mu \mathrm{g} / \mathrm{ml}$ streptomycin, at $37^{\circ} \mathrm{C}$ in a $5 \% \mathrm{CO}_{2}$ atmosphere incubator. Cells were treated with SW from a prepared stock solution in PBS, added to the culture medium to obtain final concentrations indicated as in each experiment. Equivalent volume of PBS was used as vehicle.

\section{Cell viability assay}

The effects of SW on cell viability were determined using the MTT assay. Briefly, $1 \times 10^{4}$ cells per well were plated in 96-well culture plates. After overnight incubation, the cells were treated with different concentrations of $\operatorname{SW}(0,1.5,3,6,12$ or $24 \mu \mathrm{M})$ for $24 \mathrm{~h}$. The cells were treated with $50 \mu \mathrm{l}$ of $5 \mathrm{mg} / \mathrm{ml}$ MTT and the resulting formazan crystals were dissolved in dimethyl sulfoxide (DMSO). The absorbance was measured by microplate spectrophotometer (Bio-tek Instruments, Inc., Winooski, US) at $570 \mathrm{~nm}$. Results were expressed as percentage of the controls, which were arbitrarily assigned $100 \%$ viability.

\section{Apoptosis assessment by DAPI and AO/EB staining}

Cells in exponential growth were seeded into 24-well culture plates. After overnight incubation, the cells were exposed to SW. For DAPI staining, the treated cells were fixed with $80 \%$ ethanol at room temperature for $30 \mathrm{~min}$. The fixative was removed and the cells were washed with PBS for 3 times, and then incubated with DAPI $(1 \mu \mathrm{g} / \mathrm{ml})$ for $45 \mathrm{~min}$ at room temperature in the dark. For AO/EB staining, the cells without fixation were loaded with a $100 \mu \mathrm{l}$ fresh-prepared AO/EB staining solution $(100 \mu \mathrm{g} / \mathrm{ml})$, then immediately observed under a Nikon fluorescence microscope (Nikon Inc., Japan) in less than 20 min. 


\section{Observation of ultrastructural morphology}

Transmission electron microscope: After SW treatment, the cells were fixed with $4 \%$ glutaraldehyde, and postfixed with $1 \%$ OsO4. Then samples were dehydrated in graded ethanol solutions, followed by embedment and section. Ultrathin sections were stained with uranyl acetate and lead citrate, and then observed under a transmission electron microscope (JEM-1230, Tokyo, Japan) at $60 \mathrm{KV}$.

Scanning electron microscope: Cells were seeded on cover slips and treated with $12 \mu \mathrm{M}$ of SW for $24 \mathrm{~h}$, and then washed and fixed in $2.5 \%$ glutaraldehyde in PBS for 30 min followed by dehydration in a series of ethanol solutions of decreasing dilution. After critical point dryer and ion sputter were performed, cells were observed under a scanning electron microscope (JSM-6360LV, Tokyo, Japan).

\section{DNA fragmentation assay}

After experimental treatment, both adherent and floating cells were collected and washed with PBS. Pellets were then lysed with DNA lysis buffer $(20 \mathrm{mM}$ EDTA, $100 \mathrm{mM}$ Tris, $\mathrm{pH}$ 8.0, 0.8\% SDS) at room temperature for $20 \mathrm{~min}$. After centrifugation for $5 \mathrm{~min}$ at $12000 \times g$, the supernatants were collected and treated with RNase A (final concentration, $500 \mu \mathrm{g} / \mathrm{ml}$ ) for $30 \mathrm{~min}$ at $37^{\circ} \mathrm{C}$, followed by digestion with proteinase $\mathrm{K}$ (final concentration $500 \mu \mathrm{g} / \mathrm{ml}$ ) for $2 \mathrm{~h}$ at 55 ${ }^{\circ} \mathrm{C}$. The DNA was extracted using the phenol / chloroform / isoamylol (25:24:1), precipitated with ethanol, dissolved in TE buffer (10 mM Tris, $\mathrm{pH}$ 8.0, $1 \mathrm{mM}$ EDTA), and subjected to $2 \%$ agarose gel electrophoresis for DNA fragmentation analysis.

\section{Flow cytometry analysis}

Annexin V-FITC / PI apoptosis detection kit (Becton-Dickinson, US) was used for apoptosis detection according to the manufacturer's protocol. Cells were washed twice with PBS and resuspended in 100 $\mu \mathrm{l} 1 \times$ Annextin $\mathrm{V}$ binding buffer containing $5 \mu \mathrm{l}$ of Annexin V-FITC and $5 \mu \mathrm{l}$ of PI. After incubation in the dark for $10 \mathrm{~min}$ at room temperature, cells were diluted with $400 \mu \mathrm{l} 1 \times$ Annextin V binding buffer and analyzed by flow cytometry (Beckman Coulter, Inc. Fullerton, CA. US).

\section{Caspase activity assay}

Caspases activities were measured by colorimetric assay kits (BioVision, Inc., Mountain View, CA, US) according to the manufacture's recommendations. Briefly, cells were pelleted and lysed on ice, protein concentration was measured using BCA Protein Assay Reagent (Pierce, Rockford, IL, US), then $200 \mu \mathrm{g}$ of protein was incubated with each caspase substrate at $37^{\circ} \mathrm{C}$ in a microplate for $4 \mathrm{~h}$. Samples were read at $405 \mathrm{~nm}$ in microplate spectrophotometer (BioTek Instruments, Inc., Winooski, US).

\section{Western blot analysis}

The SW-treated cells were collected and washed with ice-cold PBS, then treated with ice-cold RIPA lysis buffer (Beyotime Inst. Biotech, Beijing, China) with $1 \mathrm{mM}$ phenylmethyl sulfonylfluoride (PMSF). Cell lysates were centrifuged at $12000 \times g$ at $4{ }^{\circ} \mathrm{C}$ for 5 min. The proteins of mitochondrial and cytosolic fraction were isolated using the Mitochondria / cytosol Fractionation Kit (BioVision, Inc., Mountain View, CA, US) according to the manufacturer instructions. The protein concentration was determined using the BCA Protein Assay Kit (Pierce, Rockford, IL, US). Equivalent amounts of proteins samples were uploaded and separated by $12 \%$ SDS-PAGE and then electrotransferred to polyvinylidene difluouride (PVDF) membrane (Millipore Corp, Atlanta, GA, US). The membranes were blocked in 5\% non-fat dry milk in PBS-T at room temperature for $1 \mathrm{~h}$, and then incubated with indicated primary antibodies over night at $4^{\circ} \mathrm{C}$, followed by horseradish peroxidase-conjugated secondary antibodies at room temperature for $1 \mathrm{~h}$. The signal was detected by enhanced cheniluminescence (ECL) reagents (Pierce, Rockford, IL, US).

\section{Real-time RT-PCR analysis}

Total RNA was isolated from SW-treated cells and reverse transcribed with MMLV reverse transcriptase and oligodT primers. Quantitation of genes coding for Bcl-2 was performed using SYBR Premix

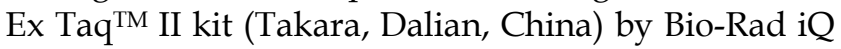
5 Real Time PCR System. The $\beta$-actin gene was used as an endogenous control. The primer sequences were: TTGAGGAAGTGAACATTTCGGTG (forward), AGGTTCTGCGGACTTCGGTC (reverse) for Bcl-2; AGTTGCGTTACACCCTTTCTTG (forward), TCACCTTCACCGTTCCAGTTT (reverse) for $\beta$-actin. The gene expression fold changes were calculated using cycle time $(\mathrm{Ct})$ values as described previously [21].

\section{Antitumor activity in vivo}

Female congenital athymic BALB/c nude $(\mathrm{nu} / \mathrm{nu})$ mice were purchased from Shanghai National Center for Laboratory Animals (Shanghai, China) and maintained in pathogen-free conditions. Exponentially growing A549 cells suspended in serum-free medium were injected subcutaneously into the back of the 4 -weeks old mice $\left(1 \times 10^{6}\right.$ cells in $\left.100 \mu \mathrm{l}\right)$. After tumor transplantation for 1 week, mice were divided randomly into three groups $(n=6)$ and orally 
administrated PBS (control group), $1 \mathrm{mg} / \mathrm{kg} / \mathrm{d}$ or 2.5 $\mathrm{mg} / \mathrm{kg} / \mathrm{d}$ does of SW in PBS in a $0.2-\mathrm{ml}$ volume, respectively, for 15 consecutive days. These doses are chosen as safe and effective in mice model according to the previous report [8]. The length (a) and width (b) of tumor were regularly measured for 3-4 times every week by a caliper and the tumor volumes were then calculated according to the formula $\left[\left(a \times b^{2}\right) / 2\right]$. At the termination of the experiment, xenograft tumors were excised and weighed to record wet tumor weight. A portion of the tumors from control and treated animals were fixed in $4 \%$ paraformaldehyde, embedded in paraffin, and cut into $6 \mu \mathrm{m}$ sections for histologic study, and that the rest were used for preparation of tumor lysate used in further experiments. The animal experiments were performed in accordance with the 'Guidelines for Animal Experimentation' of the Forth Military Medicine University.

\section{TUNEL assay}

Xenograft tumors were fixed in $4 \%$ paraformaldehyde, embedded in paraffin and cut into $6 \mu \mathrm{m} \mathrm{sec-}$ tions. Terminal deoxynucleotidyl transferase-mediated dUTP nick end labeling (TUNEL) assay was conducted to study DNA fragmentation using the in situ cell death detection kit (Beyotime Inst. Biotech, Beijing, China) according to the manufacturer's instructions. After mounting the TUNEL positive cells, the sections were observed at $\times 400$ magnification under a Nikon microscope (Nikon Inc., Japan).

\section{Immunohistochemistry analysis the expres- sion of $\mathrm{Bax}$ and $\mathrm{BCl}-2$}

Fresh tumor tissue sections were incubated with primary antibodies against Bax (1:100) and Bcl-2 (1:100) (Santa Cruz Biotechnology, US), biotinylated secondary antibody IgG, respectively, followed visually using SABC kit according to its protocol (Maixin Biological Technology Company, Fuzhou, China). The tissue sections were viewed at $\times 400$ magnification under a Nikon microscope (Nikon Inc., Japan).

\section{Statistical analysis}

Data are expressed as the means \pm SD. For each assay, student's $t$-test was used for statistical comparison. A probability of $p<0.05$ was considered significant.

\section{Results}

\section{SW inhibits the growth of various human lung cancer cell lines}

Firstly, we investigated the effects of SW treatment on the growth of various lung cancer cell lines, including A549, Calu-3, H1299 and SPC-A-1. As shown in Fig. 1, SW inhibited the growth of these cell lines in a concentration-dependent manner. $3 \mu \mathrm{M}$ of SW significantly reduced the cell viabilities of all tested cell lines after $24 \mathrm{~h}$ exposure.

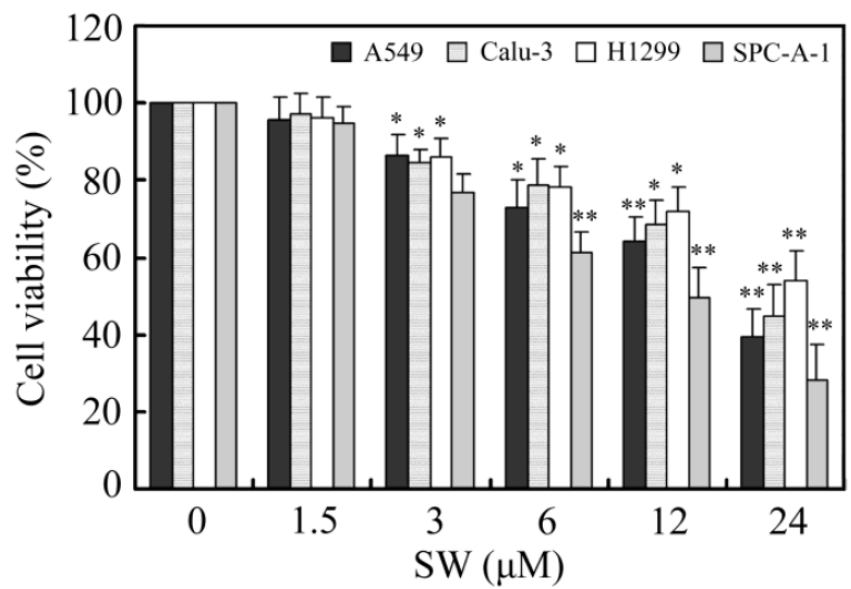

Figure I. The effects of SW treatment on different lung cancer cell lines. Cells were seeded in 96-well plates and treated with various concentrations of SW for $24 \mathrm{~h}$. After the end of treatment, cell viabilities were determined by MTT assay. The values were calculated relative to the control group $(0 \mu \mathrm{M})$. The results are mean \pm SD and representative of three independent experiments. $* p<0.05$; ** $p<0.01$ versus the control group $(0 \mu \mathrm{M}$ of SW).

\section{SW treatment induces apoptosis in human lung cancer A549 cells}

To determine whether the observed decrease in cell viability was associated with apoptosis, we examined the nuclear morphology using a Nikon fluorescence microscope. A549 cells were treated with different concentrations $(0,3,6,12$ and $24 \mu \mathrm{M})$ of SW for $24 \mathrm{~h}$ (Fig. 2A, B), or $12 \mu \mathrm{M}$ of SW for indicated times (Fig. 2C, D), followed by DAPI and AO/EB staining. The control cells did not appear significant changes in cell nuclei and cell membrane integrity, whereas SW-treated cells appeared different extent of chromatin condensation, nuclear fragmentation and destruction of cell membrane integrity after $24 \mathrm{~h}$ of incubation with different concentrations of SW, particularly with $24 \mu \mathrm{M}$ of SW (Fig. 2A, B). Typical apoptotic nuclei were observed as early as $12 \mathrm{~h}$ in cells treated with $12 \mu \mathrm{M}$ of SW (Fig. 2C, D). Characteristically morphological changes of apoptosis were also observed under transmission and scanning electron microscope in A549 cells treated with $12 \mu \mathrm{M}$ of SW for $24 \mathrm{~h}$, including cell shrinkage, volume reduction, chromatin condensation, cell blebbing and formation of membrane embedded apoptotic bodies (Fig. 2E, F). 

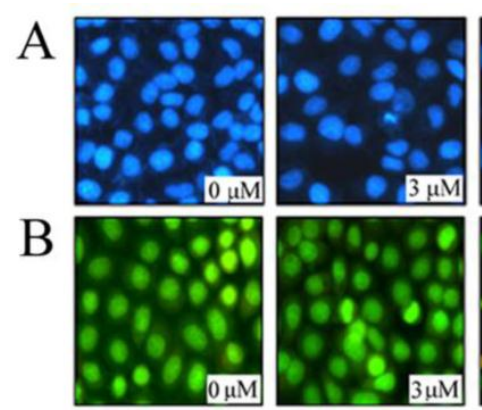

C

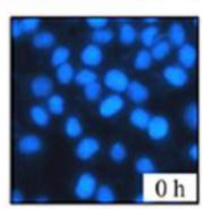

$\mathrm{D}$
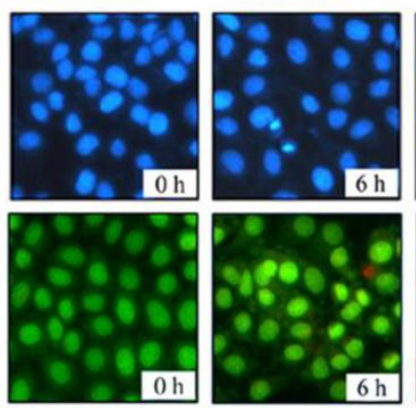

G

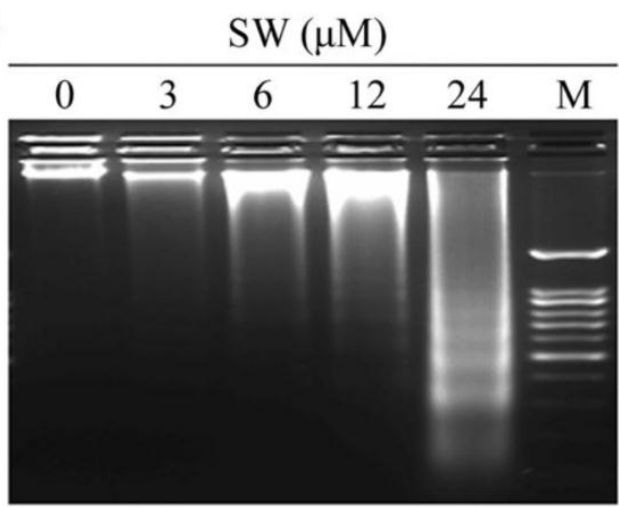

$\mathrm{H}$

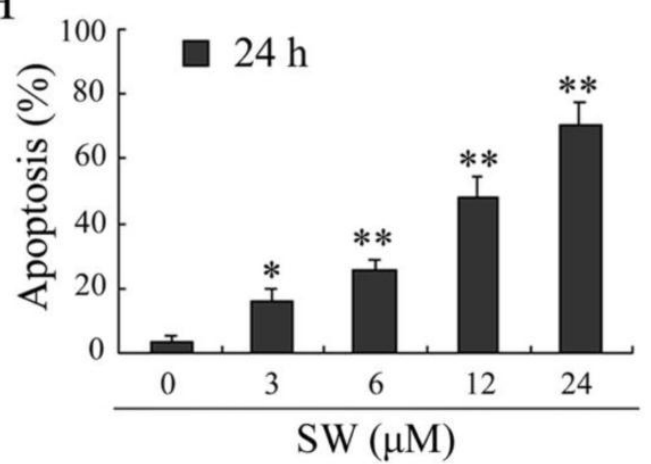

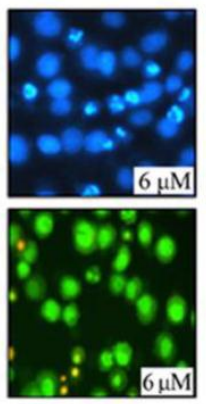
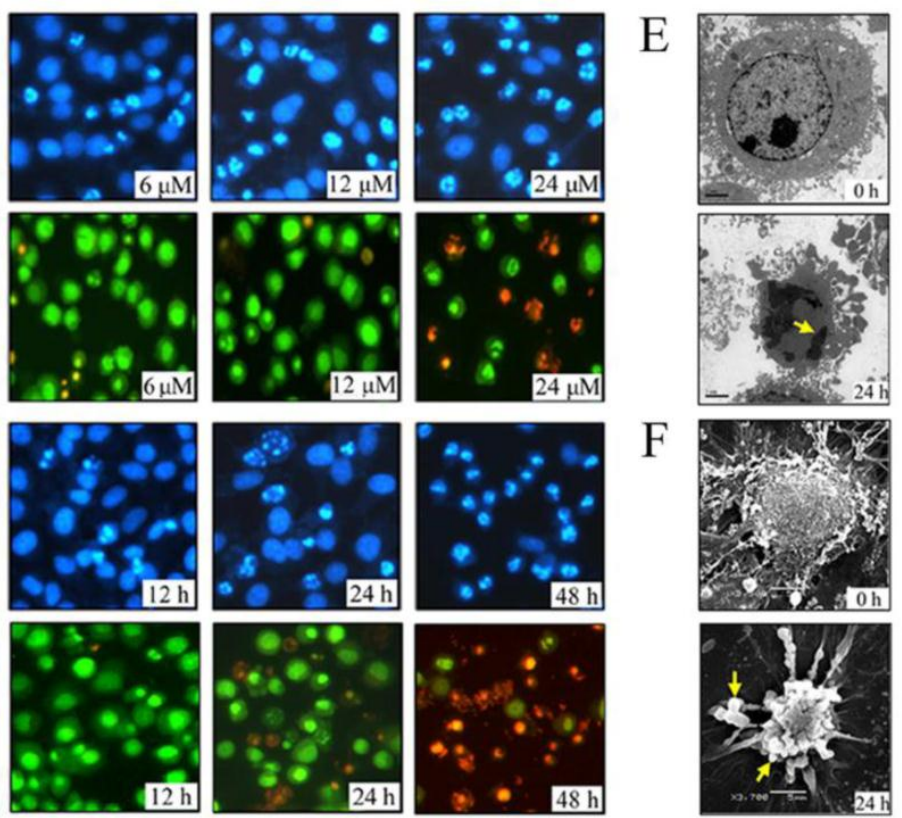

$\mathrm{F}$
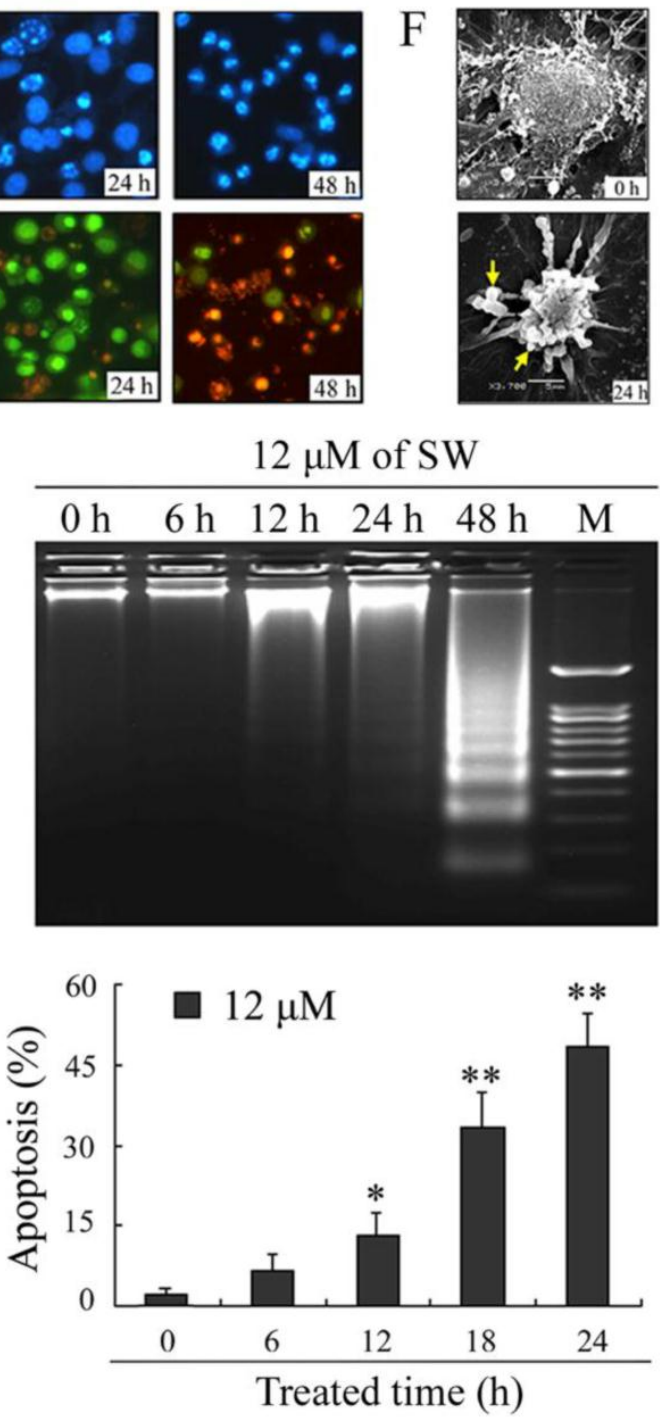

Figure 2. SW induces concentration- and time-dependent apoptosis in A549 cells. (A-D) Cells were treated with SW at different concentrations (0-4 $\mu \mathrm{M})$ for $24 \mathrm{~h}(\mathrm{~A}, \mathrm{~B})$ or treated with $12 \mu \mathrm{M}$ of SW for different times $(0-48 \mathrm{~h})(\mathrm{C}, \mathrm{D})$. Nuclear morphological changes in A549 cells were observed under fluorescent microscope after DAPI or AO/EB staining (400x). (E, F) Cells were treated with $12 \mu M$ of $\mathrm{SW}$ for $24 \mathrm{~h}$. Ultrastructural morphology was visualized under transmition electron microscopy (E) and scanning electron microscopy (F). Arrows show chromatin condensation (E) and membrane embedded apoptotic bodies (F). (G) Induction of DNA fragmentation. DNA isolated from SW-treated cells was subjected to $2 \%$ agarose gel electrophoresis, followed by visualization of bands and photography. $(\mathrm{H})$ Apoptosis rate of A549 cells. SW-treated cells were stained with Annexin V-FITC and PI for 10 min at room temperature, followed by FCM analysis. The Annexin $V$ positive cells were regarded as apoptotic. The results are mean \pm SD and representative of three independent experiments. $* p<0.05$, ** $p<0.01$ versus the control group. 
Besides changes in cell morphology, DNA fragmentation of SW-treated cells was also examined by observation of the formation of DNA ladder. As shown in Fig. 2G, DNA ladder appeared to be more evident with the increasing of SW concentration, however, no DNA fragments were observed in the control groups (Fig. 2G, left panel). When the cells were treated with $12 \mu \mathrm{M}$ of SW, DNA fragments were observed at $12 \mathrm{~h}$, and more evident at $48 \mathrm{~h}$ (Fig. 2G, right panel). The SW-induced apoptosis was further determined by flow cytometry using Annexin V/PI dual staining. When A549 cells were treated with different concentrations $(0-24 \mu \mathrm{M})$ for $24 \mathrm{~h}$, the average percentage of apoptotic cells (Annexin $\mathrm{V}^{+}$) increased from $3.2 \%$ of the control to $71.5 \%$ (Fig. $2 \mathrm{H}$, left panel). When the cells were treated with $12 \mu \mathrm{M}$ of SW for indicated time (0-24 h), the rate of apoptotic cells significantly increased over $12 \mathrm{~h}$, and reached about $42.7 \%$ over $24 \mathrm{~h}$ of incubation (Fig. $2 \mathrm{H}$, right panel). Taken together, these results demonstrated that SW treatment induced A549 cells apoptosis in a concentrationand time-dependent manner. In addition, SW-induced apoptosis was also observed in Calu-3 cells, H1299 cells and SPC-A-1 cells (Fig. 3A, B).

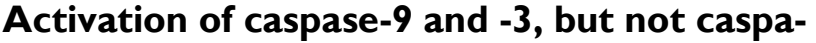 se-8, is involved in SW-induced apoptosis}

In the present study, we investigated the possible mechanisms of SW-induced apoptosis in A549 cells. Since caspases are known to play a pivotal role in mediating various apoptotic signaling, we measured the activity of initiator caspases (caspase- 8 and -9) and effector caspase (caspase-3) in SW treated cells. As shown in Fig. 4A, exposure of A549 cells to 12 $\mu \mathrm{M}$ of SW led to increased levels of activated caspase-9 and -3 and caused cleavage of PARP in a time-dependent manner during the treatment period. The activated forms of caspases- 9 and -3 were observed as early as $6 \mathrm{~h}$. In contrast, the cleavage procaspase-8 was not observed in this study. The SW-induced caspases activation was further confirmed by measuring the enzymatic activities of caspases- $8,-9$, and -3 using the colorimetric assay kits. As shown in Fig. 4B, SW-treatment significantly increased the activities of caspases- 9 and -3 but had no effects on the activity of caspase- 8 during the treated period.

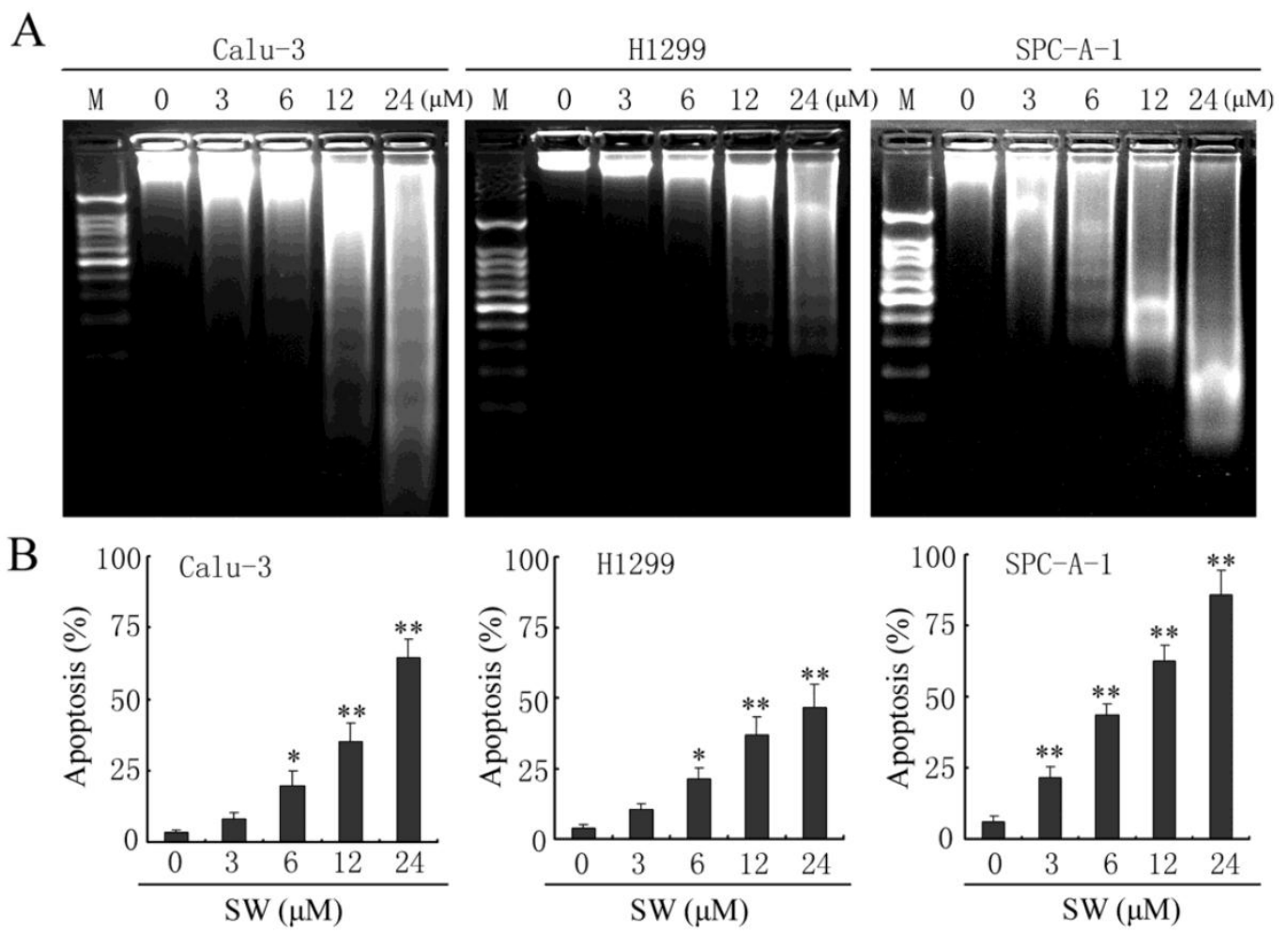

Figure 3. SW induces apoptosis in Calu-3, HI299 and SPC-A-I cells. (A) Calu-3, HI299 and SPC-A-I cells were treated with the indicated concentrations of SW for $48 \mathrm{~h}$. DNA was extracted and analyzed on $2 \%$ agarose gel. (B) Calu-3, HI 299 and SPC-A-I cells were treated with the indicated concentrations of SW for $24 \mathrm{~h}$, followed by Annexin V / PI staining and FCM analysis. The Annexin $\mathrm{V}$ positive cells were regarded as apoptotic. The results are mean \pm SD and representative of three independent experiments. $* p<0.05$, $* * p<0.0$ I versus the control group $(0 \mu \mathrm{M})$. 

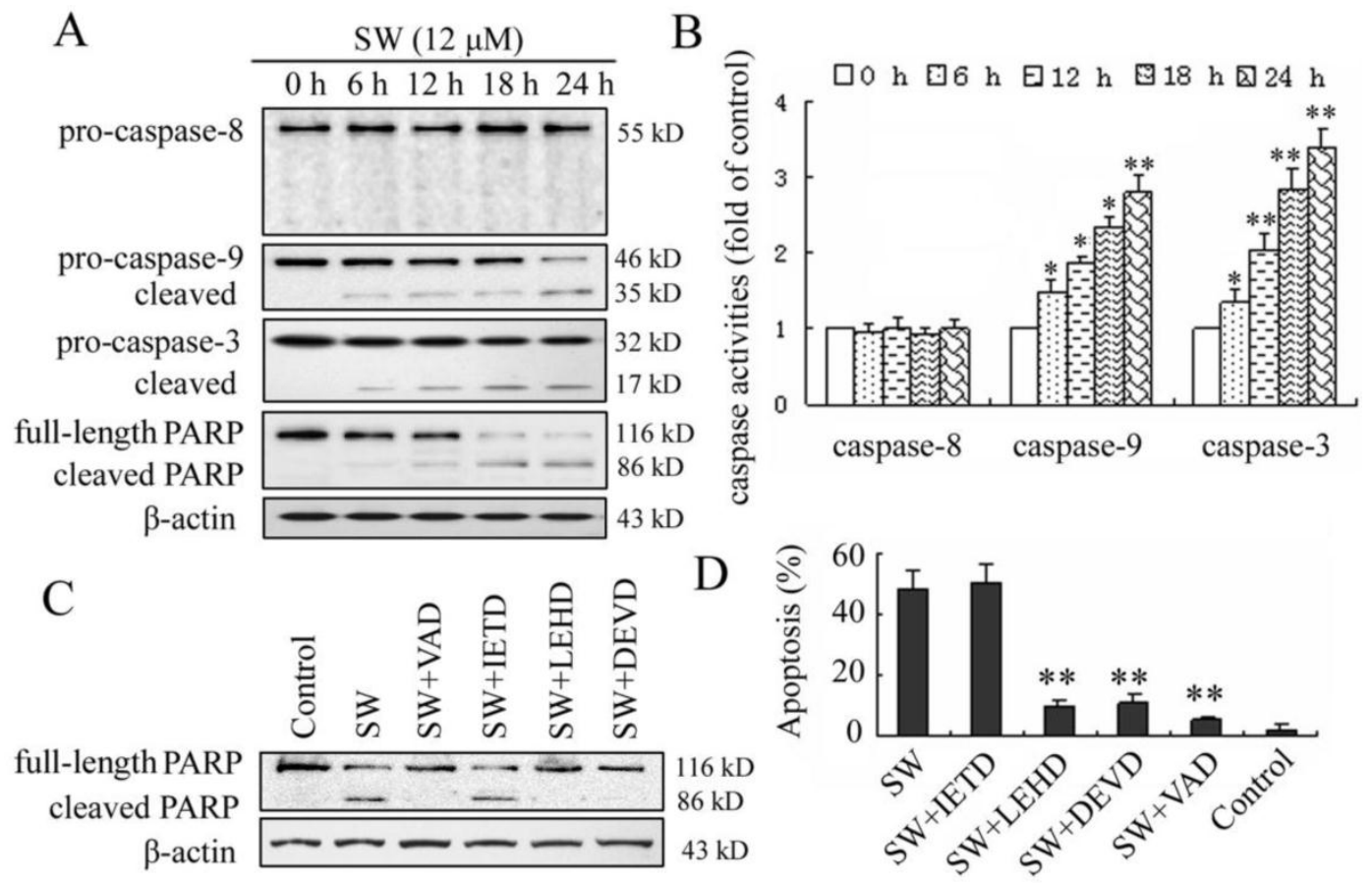

Figure 4. SW-induced apoptosis is mediated by activation of caspase-9 and -3. (A) A549 cells were treated with $12 \mu M$ of SW for indicated time. Whole cell lysates were subjected to western blot analysis to detect total and activated caspase-8, $-9,-3$ and PARP. The data shown are representative of three independent experiments. (B) Caspase activities in cells treated with SW. Cells were incubated with $12 \mu \mathrm{M}$ of SW for indicated times and the enzymatic activities of caspases-8, -9 , and -3 were measured using the colorimetric assay kits. The results are mean \pm SD and representative of three independent experiments. $* p<0.05, * * p<0.0$ l versus the control group $(0 \mathrm{~h})$. (C) Effect of caspase inhibitors on SW-induced cleavage of PARP. Cells were incubated with $20 \mu M$ of caspase inhibitors, z-VAD-fmk, z-DEVD-fmk, z-IETD-fmk or z-LEHD-fmk for I h and then co-incubated with $12 \mu \mathrm{M}$ of SW for $24 \mathrm{~h}$. Expression level of PARP was analyzed by Western blot. The data shown are representative of three independent experiments. (D) Effects of caspase inhibitors on SW-induced apoptosis. A549 Cells were treated as in C. Rate of apoptosis was evaluated by FCM analysis. Data are mean \pm SD and representative of three independent experiments. $* * p<0.01$ versus $S W$ alone without inhibitor.

To further determine the involvement of caspases in SW-induced apoptosis, four caspase inhibitors, z-VAD-fmk (pan caspase inhibitor), z-IETD-fmk (caspase-8 specific inhibitor), z-LEHD-fmk (caspase-9 specific inhibitor) and z-DEVD-fmk (caspase-3 specific inhibitor) were used to block intracellular protease, and then the SW-induced cleavage of PARP and apoptotic rate was detected using western blot and flow cytometry assay. Z-VAD-fmk, z-LEHD-fmk, or z-DEVD-fmk inhibited SW-induced cleavage of PARP, whereas z-IETD-fmk (caspase-8 inhibitor) did not (Fig. 4C). In consistent with this result, the apoptosis of SW-treated cells was prevented almost wholly by $z$-VAD-fmk, in part by z-LEHD-fmk and z-DEVD-fmk, but not by z-IETD-fmk after $24 \mathrm{~h}$ of co-treatment (Fig. 4D). These results suggested that the SW-induced apoptosis was dependent on the activation of caspases and mainly executed through the activation of caspase- 9 and -3 .

\section{SW treatment activates the mitochondrial apoptotic pathway involving the regulation of Bcl-2 family members}

Apoptosis is usually induced through two distinct signaling pathways: the death receptor pathway and the mitochondrial pathway. The death receptor pathway is usually triggered by ligation of death receptors such as Fas or tumor necrosis factor receptor, which recruits fas associated protein with death domain (FADD) and procaspase-8 to form a death-inducing signaling complex, leading to caspase- 8 proteolytic activation. Activated caspase- 8 can not only directly activates downstream caspase-3, but also cleave Bid to truncated Bid (tBid), which in turn activates the mitochondrial pathway [22]. Consistent with the results of caspase-8, SW treatment also did not affect the levels of Fas and FasL, or promote cleavage of Bid (Fig. 5A, B). These results further suggested that SW treatment might not activate Fas-mediated death receptor pathway in A549 cells. 
The mitochondrial pathway usually involves the release of mitochondrial cytochrome $\mathrm{c}$ to the cytosol. Once released, cytochrome c combines with apoptotic protease activating factor 1 (Apaf-1) and procaspase- 9 to form the apoptosome in the presence of ATP, resulting in the activation of caspse- 9 and caspase- 3 [23]. The Bcl-2 family members are known to play important roles in controlling the release of cytochrome $\mathrm{c}$ from mitochondria. Upon apoptotic signals, pro-apoptotic Bcl-2 members, such as Bax, Bak or Bid, are activated; in contrast anti-apoptotic Bcl-2 member $\mathrm{Bcl}-2$ and $\mathrm{Bcl}-\mathrm{X}_{\mathrm{L}}$ can prevent this occurrence [24]. The imbalance of expression of pro- and anti-apoptotic proteins is associated with the ultimate fate of cells [25]. To assess whether mitochondrial pathway is involved in SW-induced apoptosis, we evaluated the expression levels of Bax and Bcl-2 by western blot. As shown in Fig. 5B, exposure of A549 cells to $12 \mu \mathrm{M}$ of

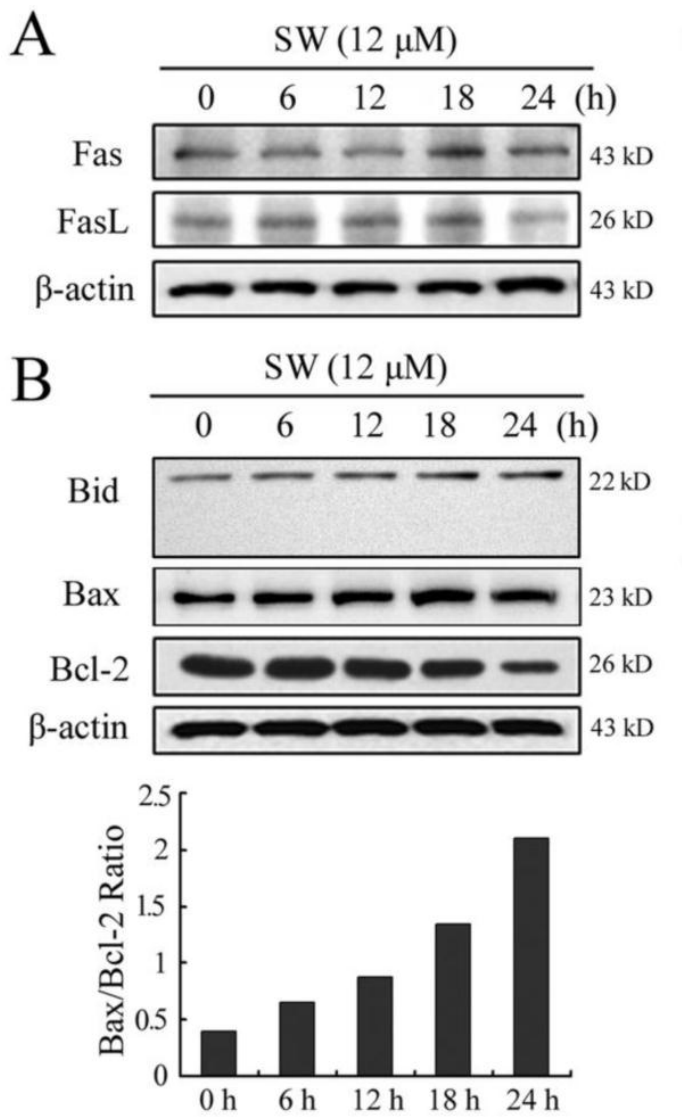

SW for different times (0-24 h), Bax protein levels increased, whereas Bcl-2 protein levels decreased gradually with time. Thus, SW treatment increased the ratio of $\mathrm{Bax} / \mathrm{Bcl}-2$, which is in favor of the occurrence of apoptosis. The reduction of Bcl-2 in mRNA levels might contribute to the shift in the Bax/Bcl-2 ratio (Fig. 5C). Next, we detected the location of Bax and cytochrome $\mathrm{c}$ in the proteins extracts from both mitochondrial and cytosolic fractions of SW-treated cells. A translocation of Bax from cytosol to mitochondria was observed as early as $6 \mathrm{~h}$ post-treatment (Fig. 5D). Consistent with this, a time-dependent decrease in mitochondrial cytochrome $\mathrm{c}$ and a concomitant increase in the cytosolic fraction were also observed (Fig. 5D). These results suggested that SW treatment-induced apoptosis was mainly through the activation of mitochondrial pathway.

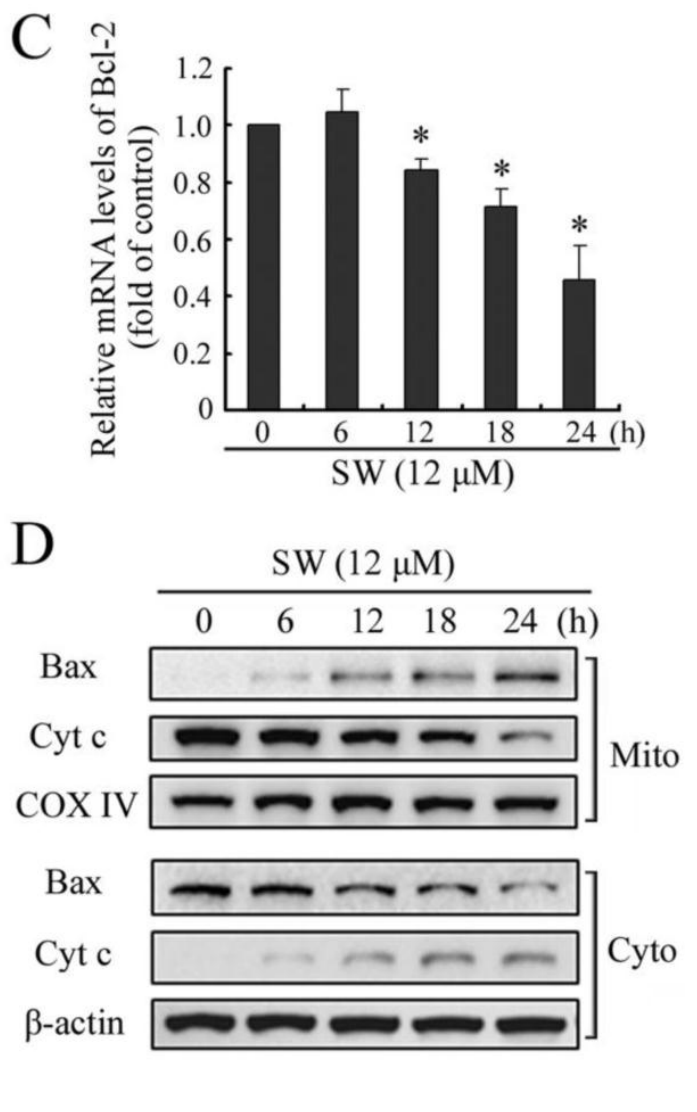

Figure 5. SW-induced A549 cell apoptosis is mediated by the activation of mitochondrial pathway. A549 cells were incubated with $12 \mu \mathrm{M}$ of SW for indicated time. The cell lysates were subjected to Western blot analysis, while total RNA was extracted and used for real-time RT-PCR assay. (A) SW treatment did not affect the levels of Fas or FasL. (B) SW treatment did not promote the cleavage of Bid, but increased the ratio of $\mathrm{Bax} / \mathrm{Bcl}-2$. The values were calculated from the bands corresponding to $\mathrm{Bax}$ and $\mathrm{Bcl}-2$ that normalized to $\beta$-actin. (C) SW treatment decreased the expression of $\mathrm{Bcl}-2$ at mRNA levels. The results are mean \pm SD and representative of three independent experiments. ${ }^{*} p<0.05$ versus the control group $(0 \mathrm{~h})$. (D) SW treatment promoted Bax translocation and cytochrome c release. Cells were treated with $12 \mu \mathrm{M}$ of SW for the indicated times. The cytosolic and mitochondrial fraction proteins were collected and then detected by western blot. COX IV and $\beta$-actin were used as internal controls for the mitochondrial fractions and the cytosolic fraction, respectively. All the data shown are representative of three independent experiments. 


\section{SW intake inhibits growth of A549 xenografts in athymic nude mice}

SW has been shown to be effectively induced apoptosis in A549 cells; therefore, we further extended our study to determine whether these events occur in vivo using a xenograft mouse model. Athymic nude mice xenografted with A549 cells were divided into control group and SW-treated groups wherein SW was administered at doses of 1 or $2.5 \mathrm{mg} / \mathrm{kg} /$ day for 15 days. Contrast with control group, tumor volume was inhibited by $27 \%$ and $41 \%(p<0.05)$ and the wet weight of tumor was decreased by $24 \%$ and $36 \%(p<$ 0.05 ) in 1 and $2.5 \mathrm{mg} / \mathrm{kg} /$ day SW-treated group, respectively, at the termination of the experiment (Fig. 6A, B). SW administration did not seem to induce any adverse effects as judged by monitoring body weight and livers and kidneys (data not shown). No pathological changes were observed in the lung histology of mice from the SW-treated group (Fig. 6C, left panel). Furthermore, we evaluated the effects of SW intake on the induction of apoptosis and apoptosis-associated molecules in tumor xenografts. TUNEL assay showed evident in situ apoptosis in A549 tumor sections at 1 and $2.5 \mathrm{mg} / \mathrm{kg} /$ day of SW-treated groups, but not in the sections of control group (Fig. 6C mid panel). Immunohistochemistry and western blot analysis showed that SW administration resulted in an increase in the protein levels of Bax, decrease in Bcl-2 and simultaneous activation of caspase-3, the redistribution of Bax and cytochrome c compared to mice receiving vehicle treatment (Fig. $6 \mathrm{C}$ right panels, D), which is consistent with our findings in cell culture. These data suggested that SW administration inhibited A549 xenograft tumors growth via induction of tumor cell apoptosis.

\section{Discussion}

Previous studies have shown that SW inhibits a number of human tumors including colorectal carcinoma, melanoma, hepatoma, breast carcinoma, pate malignant tumor and gastric carcinoma as well as in murine lymphoma tumor cells, melanoma cell, S180 ascites tumor and rat glioma cells in vitro or in vivo $[8-10,12,26]$. In the present study, we evaluated the effects of SW on several human lung cancer cell lines in vitro and $\mathrm{A} 549$ in vivo. The results demonstrated that SW reduced the survival of the cancer cells and inhibited the growth of A549 xenograft tumors through induction of apoptosis. In addition, we provided evidence that SW induced apoptosis in A549 cells through the cytochrome c-mediated, caspa- se-dependent pathway.

Many previous reports have indicated that a lot of anticancer drugs or cancer chemopreventive agents act through the induction of apoptosis to prevent tumor promotion and progression [27, 28]. Sun et al. reported that the growth inhibition effect of SW on SGC-7901 cells and C6 glioma cells might be through induction of apoptosis $[9,10]$. In the current in vitro study, we observed that SW inhibited cell growth through induction of apoptosis in A549 cells in a concentration- and time-dependent manner, as evident by the phosphatidylserine externalization, appearance of membrane enclosed apoptotic bodies, DNA laddering fragment, as well as caspases activation and PARP cleavage. SW has been reported to inhibit solid tumors through direct and indirect actions on the tumor cells in vivo, and the two possible mechanisms have been elucidated in previous studies. Firstly, it inhibits tumor cell metastasis and invasion by modifying the expression of glycoprotein on the tumor cell surface as an oligosaccharide-processing inhibitor. Tumor cells cultured in the presence of SW show loss of invasiveness into extracellular matrix, as well as loss of organ colonization potential when injected i.v. into mice [29]. Secondly, SW acts as an anticancer immunomodulatory agent. SW alleviates tumor-induced immune suppression and stimulates NK cell, macrophage, and LAK cell-mediated tumoricide activity [16, 26, 30, 31]. In this study, significant apoptosis were observed by TUNEL assay in the xenograft tumors in mice orally received SW at doses of 1 and $2.5 \mathrm{mg} / \mathrm{kg} /$ day. Our results demonstrate that SW also serves as an apoptosis inducer both in vitro and in vivo.

Next, we investigated the possible mechanisms of SW-induced apoptosis in A549 cells. Caspases have been known to play a pivotal role in the execution of apoptosis. The two major caspases activation pathways, i.e., death receptor and mitochondrial pathways, have been well described [20]. In death receptor pathway, apoptosis occurs upon the stimulation of death receptors in the cell surface to activate caspase-8. The mitochondrial pathway is dependent on the release of cytochrome $\mathrm{c}$ from mitochondria to the cytosol, resulting in the activation of caspase-9. Caspase- 8 and caspase-9 will then proteolytically activate downstream caspases, in particular caspases-3, which is essential for the morphological change and DNA fragmentation associated with apoptosis. There are also evidences that apoptosis can be induced through caspase-independent mechanism [32]. 
A

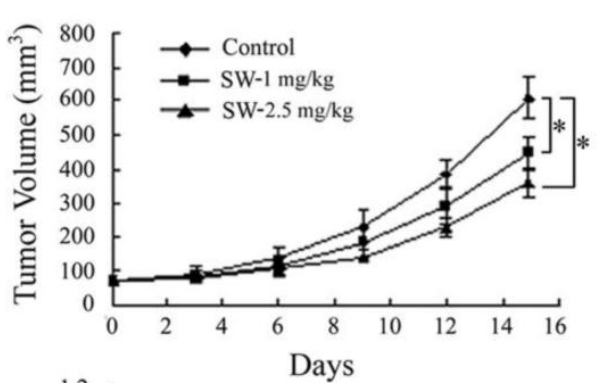

B

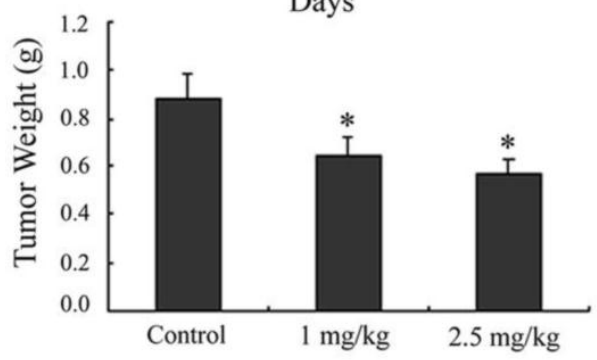

D
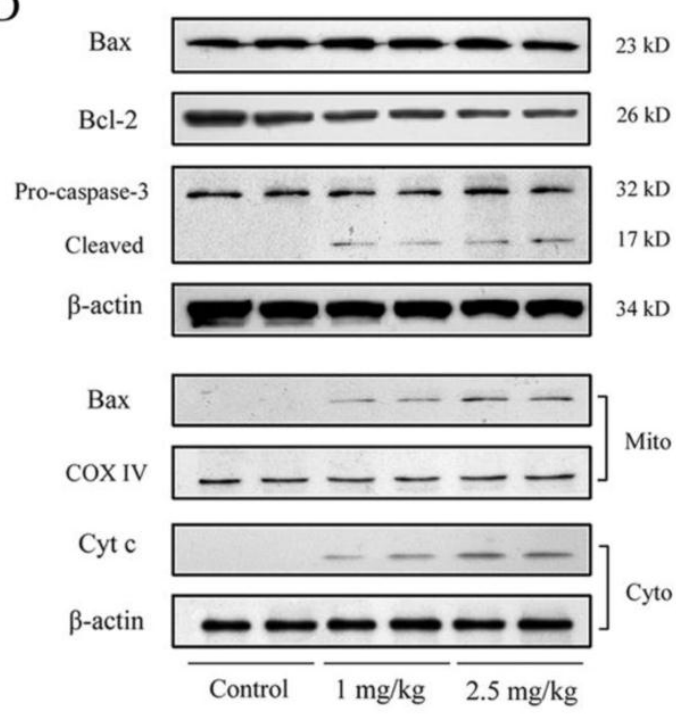

Xenograft tumor

$\mathrm{C}$

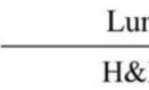

H\&E
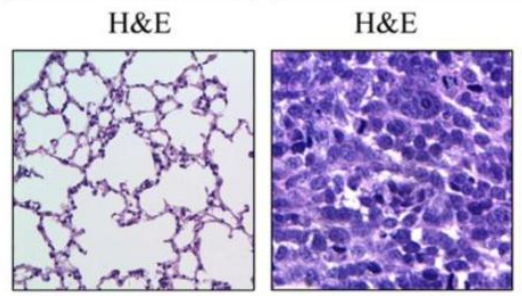

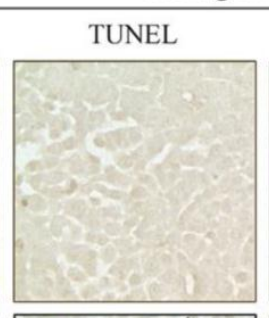
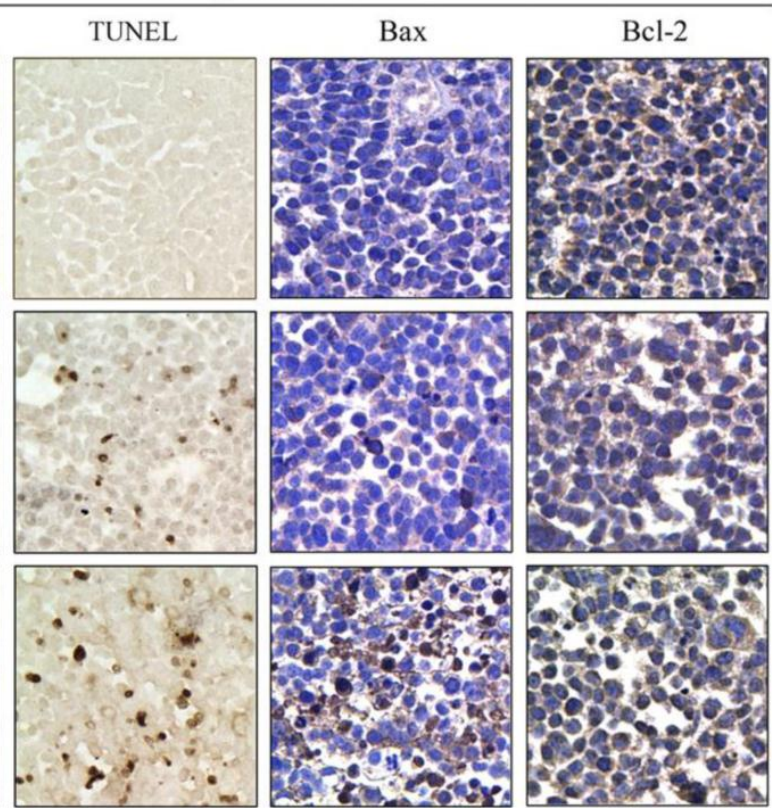

Figure 6. SW administration inhibits A549 tumor growth in athymic nude mice via induction of apoptosis. Approximately $1 \times 10^{6}$ A549 cells were injected into back of mouse, and SW was provided to mice I week after cell inoculation. Mice were divided into three groups: Group I received $0.2 \mathrm{ml}$ PBS only as control; Group II received I mg/kg SW in $0.2 \mathrm{ml} \mathrm{PBS}$; Group III received $2.5 \mathrm{mg} / \mathrm{kg}$ SW in $0.2 \mathrm{ml}$ PBS daily for 15 days. (A) Tumor volumes $\left(\mathrm{mm}^{3}\right)$ were measured regularly in two dimensions throughout the study. Data are represented as the mean of 6 tumors from each group. * $p<0.05$ versus the control group. (B) Wet weight of tumors were measured in the end of this experiment. Data are represented as the mean of 6 tumors from each group. $* p<0.05$ versus the control group. (C) The host's lung tissues were examined by H\&E staining. Tumor tissues were examined by H\&E staining, TUNEL assay and immunohistochemistry staining with anti-Bax and Bcl-2 primary antibodies. (D) Western blot analysis of cytochrome c, Bax, Bcl-2, and caspase-3 in tumor tissue lysates after intake of indicated doses of SW. The data are representative of three independent experiments.

In this study, we observed that the process of $\mathrm{SW}$-induced apoptosis involved the activation of caspase-9 and -3, and that the treatment with pan-caspase inhibitor or specific inhibitors of caspase-9 and -3 significantly prevented the SW-induced cell apoptotic effects. Thus, our results demonstrate that the SW-induced apoptosis is dependent on the activation of caspases, especially capase- 9 and -3 . As a low molecular weight and water soluble alkaloid, SW can quickly enter the cytoplasma rather than persistently stay on the cell membrane, which implies the possibility that mitochondria-mediated caspase- $9 /-3$ 
activation pathway should be responsible for the SW induced apoptosis. Coincidentally, SW treatment did not activate capase- 8 or its upstream molecules such as Fas and FasL. Just like some compounds such as sulforaphane and $\gamma$-tocotrienol, which induce apoptosis by directly impairing the mitochondrial integrity in certain cell types $[33,34]$, SW failed to activate the death receptor-mediated caspase- 8 pathway in this study.

Mitochondria play an essential role in death signal transduction and amplification of the apoptotic response. An important role of mitochondria in apoptotic signaling is the translocation of cytochrome c from the mitochondrial intermembrane compartment into the cytosol. Once released, cytochrome c together with Apaf-1 activates caspase-9, and the latter then activates caspase-3 [35]. The release of cytochrome c and cytochrome c-mediated apoptosis is controlled prominently by the members of Bcl-2 family, of which Bax and Bcl-2 have been identified as major regulators. In response to a variety of stimuli including anticancer drugs, Bax translocates to the mitochondria and inserts into the outer mitochondrial membrane, where allows the release of cytochrome c. In contrast, Bcl-2 blocks cytochrome c efflux by binding to the outer mitochondrial membrane and forming a heterodimer with Bax resulting in neutralization of its proapoptotic effects [36]. Therefore, the balance between the levels of Bcl-2 and Bax is critical in determining the fate of cells, survival or death. Results obtained in the present study demonstrated that SW-treatment increased the ratio of Bax/Bcl-2, promoted the redistribution of Bax and cytochrome $\mathrm{C}$ both in vitro and in vivo, suggesting that the increase of the ratio of $\mathrm{Bax} / \mathrm{Bcl}-2$ might be the key factor of SW-induced apoptosis. These results provide further insight into SW-induced apoptosis and deepen the mechanisms of anticancer activity of SW, and can provide a rational for developing SW to be a promising chemotherapeutic agent in future.

In summary, our results demonstrate that $\mathrm{SW}$ is an inducer of apoptosis in A549 cells. The SW-induced apoptosis is dependent on the mitochondria-mediated caspase activation and involvement of the regulation of $\mathrm{Bcl}-2$ and Bax (Fig. 7). These data provided a clue to understand the mechanisms of SW-induced apoptosis. It is probable that we are far from unveiling the complete mechanisms underlying SW induction of the growth inhibition and apoptosis of tumor cells, and that other signaling components such as p53 might be involved. Work ongoing in our laboratory is addressing these issues.

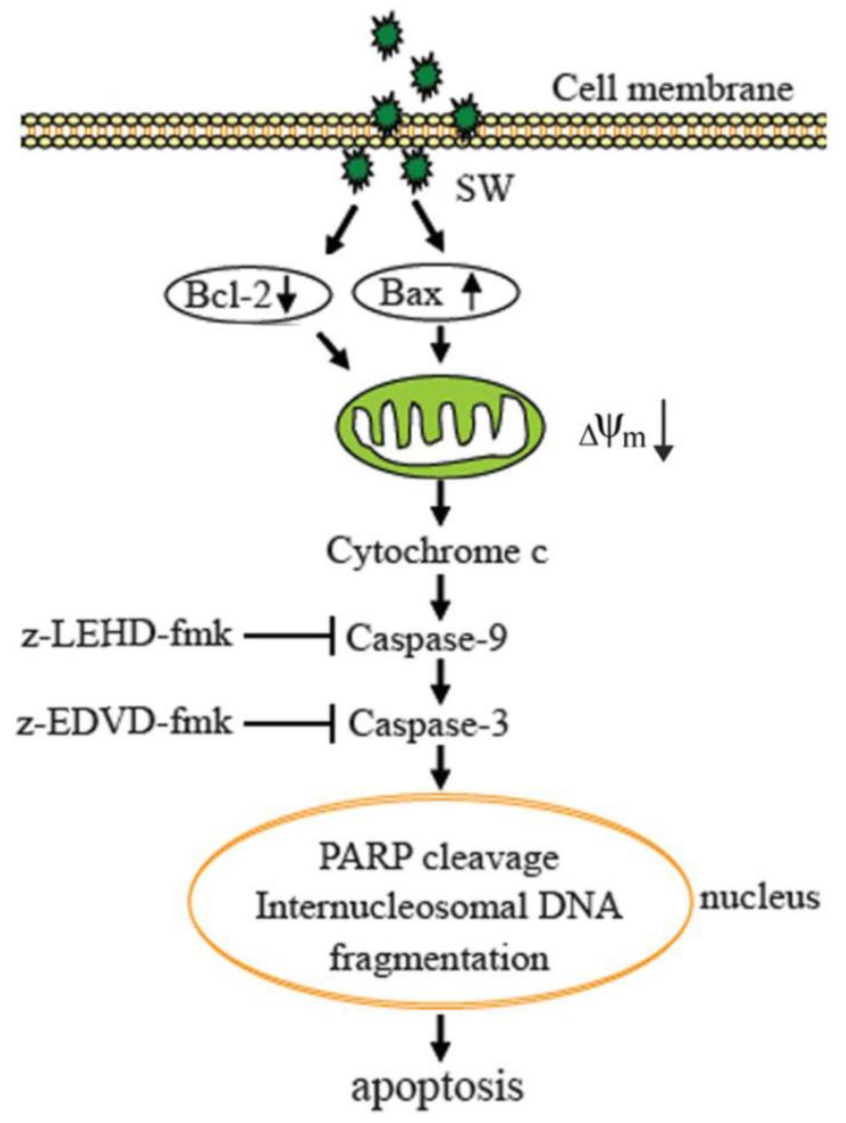

Figure 7. Proposed model of molecular mechanism of SW-induced apoptosis in A549 cells. SW treatment up-regulates Bax, down-regulates Bcl-2 expression, promotes Bax translocation to mitochondria, activates mitochondria-mediated apoptotic pathway, which in turn causes the release of cytochrome c, the activation of caspase- 9 and caspase- 3 , and the cleavage of PARP and fragmentation of internucleosomal DNA, resulting in A549 cell apoptosis.

\section{Acknowledgements}

This work was supported by the National Natural Science Foundation of China (Grant No. 31072108), the Doctoral Program of Higher Education of China (Grant No. 20090204110016, 20110204110014) and the Fundamental Research Funds for the Central Universities (QN2011064). We are grateful to Yong Zhao and Kai Lei for their kind help in the animal experiments. The authors also thank Xin He for Flow cytometry assay, and Li Cao for help in statistical analysis.

\section{Conflict of Interests}

The authors have declared that no conflict of interest exists. 


\section{References}

1. Colegate S, Dorling $\mathrm{P}$, Huxtable C. A spectroscopic investigation of swainsonine: an a-mannosidase inhibitor isolated from Swainsona canescens. Aust J Chem. 1979; 32: 2257-64.

2. Molyneux R, James L. Loco intoxication: indolizidine alkaloids of spotted locoweed (Astragalus lentiginosus). Science. 1982; 216: 190-1.

3. Cao GR, Li SJ, Duan DX, et al. The toxic principle of Chinese locoweeds (Oxytropis and Astragalus): toxicity in goats. In: James LF, Keeler RF, Cheeke PR, Bailey EM, Hegarty MP, eds. Ames: Iowa State University Press. 1992: 117-21.

4. Tong D, Mu P, Dong Q, et al. Immunological evaluation of SW-HSA conjugate on goats. Colloids and Surfaces B: Biointerfaces. 2007; 58: 61-7.

5. Tong DW, Wang JY, Mu PH, et al. Analysis of several serum enzymes and blood urea nitrogen of swainsonine-HSA immunized goats. Anim Feed Sci Tech. 2008; 142: 74-88.

6. Dennis J, Laferte S, Yagel S, Breitman M. Asparagine-linked oligosaccharides associated with metastatic cancer. Cancer cells. 1989; 1: 87-92.

7. Dennis JW, Laferte S, Waghorne C, et al. Beta 1-6 branching of Asn-linked oligosaccharides is directly associated with metastasis. Science. 1987; 236: 582-5.

8. Dennis JW, Koch K, Yousefi S, VanderElst I. Growth inhibition of human melanoma tumor xenografts in athymic nude mice by swainsonine. Cancer Res. 1990; 50: 1867-72.

9. Sun JY, Zhu MZ, Wang SW, et al. Inhibition of the growth of human gastric carcinoma in vivo and in vitro by swainsonine. Phytomedicine. 2007; 14: 353-9.

10. Sun JY, Yang H, Miao S, et al. Suppressive effects of swainsonine on C6 glioma cell in vitro and in vivo. Phytomedicine. 2009; 16: 1070-4.

11. Dennis JW, Koch K, Beckner D. Inhibition of human HT29 colon carcinoma growth in vitro and in vivo by swainsonine and human interferon-a2. J Natl Cancer I. 1989; 81: 1028-33.

12. Goss PE, Baptiste J, Fernandes B, et al. A phase I study of swainsonine in patients with advanced malignancies. Cancer Res. 1994; 54: 1450-7.

13. Goss PE, Reid CL, Bailey D, Dennis JW. Phase IB clinical trial of the oligosaccharide processing inhibitor swainsonine in patients with advanced malignancies. Clin Cancer Res. 1997; 3 : 1077-86.

14. Klein JLD, Roberts J, George M, et al. Swainsonine protects both murine and human haematopoietic systems from chemotherapeutic toxicity. Brit J Cancer. 1999; 80: 87-95.

15. Oredipe OA, Furbert-Harris PM, Laniyan I, et al. Enhanced proliferation of functionally competent bone marrow cells in different strains of mice treated with swainsonine. Int Immunopharmacol. 2003; 3: 445-55.

16. Oredipe OA, White SL, Grzegorzewski K, et al. Protective effects of swainsonine on murine survival and bone marrow proliferation during cytotoxic chemotherapy. J Natl Cancer I. 1991; 83: 1149-56.

17. Hamaguchi J, Nakagawa $H$, Takahashi $M$, et al. Swainsonine reduces 5-fluorouracil tolerance in the multistage resistance of colorectal cancer cell lines. Mol Cancer. 2007; 6: 58.

18. Santos FM, Latorre AO, Hueza IM, et al. Increased antitumor efficacy by the combined administration of swainsonine and cisplatin in vivo. Phytomedicine. 2011; 18: 1096-1101.

19. Fadeel B, Orrenius S. Apoptosis: a basic biological phenomenon with wide-ranging implications in human disease. J Int Med. 2005; 258: 479-517.

20. Ghobrial IM, Witzig TE, Adjei AA. Targeting apoptosis pathways in cancer therapy. CA-Cancer J Clin. 2005; 55: 178-94.
21. Livak KJ, Schmittgen TD. Analysis of relative gene expression data using real-time quantitative PCR and the $2^{-\Delta \Delta C t}$ method. Methods. 2001; 25: 402-8.

22. Li H, Zhu H, Xu C, Yuan J. Cleavage of BID by caspase 8 mediates the mitochondrial damage in the Fas pathway of apoptosis. Cell. 1998; 94: 491-501.

23. Li P, Nijhawan D, Budihardjo I, et al. Cytochrome c and dATP-dependent formation of Apaf-1/caspase-9 complex initiates an apoptotic protease cascade. Cell. 1997; 91: 479-89.

24. Sharpe JC, Arnoult D, Youle RJ. Control of mitochondrial permeability by Bcl-2 family members. BBA-Mol Cell Res. 2004; 1644: 107-13.

25. Yang WL, Addona T, Nair DG, et al. Apoptosis induced by cryo-injury in human colorectal cancer cells is associated with mitochondrial dysfunction. Int J Cancer. 2003; 103: 360-9.

26. Yagita M, Saksela E. Swainsonine, an inhibitor of glycoprotein processing, enhances cytotoxicity of large granular lymphocytes. Scand J Immunol. 1990; 31: 275-82.

27. Surh YJ. Cancer chemoprevention with dietary phytochemicals. Nat Rev Cancer. 2003; 3: 768-80.

28. Xu Y, Ge R, Du J, et al. Corosolic acid induces apoptosis through mitochondrial pathway and caspases activation in human cervix adenocarcinoma HeLa cells. Cancer Lett. 2009; 284: 229-37.

29. Cornil I, Kerbel RS, Dennis JW. Tumor cell surface beta 1-4-linked galactose binds to lectin(s) on microvascular endothelial cells and contributes to organ colonization. Journal Cell Bio. 1990; 111: 773-81.

30. Grzegorzewski K, Newton S, Akiyama S, et al. Induction of macrophage tumoricidal activity, major histocompatibility complex class II antigen (Iak) expression, and interleukin-1 production by swainsonine. Cancer Commun. 1989; 1: 373-9.

31. Humphries MJ, Matsumoto K, White SL, et al. Augmentation of murine natural killer cell activity by swainsonine, a new antimetastatic immunomodulator. Cancer Res. 1988; 48: 1410-5.

32. Kim RH, Coates JM, Bowles TL, et al. Arginine deiminase as a novel therapy for prostate cancer induces autophagy and caspase-independent apoptosis. Cancer Res. 2009; 69: 700-8.

33. Chu WF, Wu DM, Liu W, et al. Sulforaphane induces G2-M arrest and apoptosis in high metastasis cell line of salivary gland adenoid cystic carcinoma. Oral onco. 2009; 45: 998-1004.

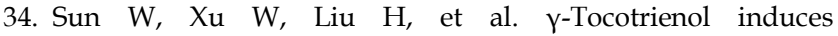
mitochondria-mediated apoptosis in human gastric adenocarcinoma SGC-7901 cells. J Nutr Biochem. 2009; 20: 276-84.

35. Kroemer G, Reed JC. Mitochondrial control of cell death. Nat Med. 2000; 6: 513-9.

36. Huang YT, Huang DM, Chueh SC, et al. Alisol B acetate, a triterpene from Alismatis rhizoma, induces Bax nuclear translocation and apoptosis in human hormone-resistant prostate cancer PC-3 cells. Cancer Lett. 2006; 231: 270-8. 